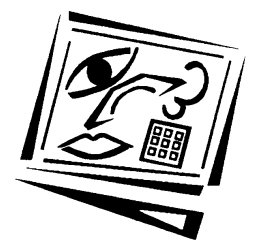

\title{
Are secondary preservice teachers well prepared to teach with technology? A case study from China
}

\author{
George Zhou and Zuochen Zhang \\ University of Windsor, Canada \\ Yueke Li \\ Liaocheng University, China
}

\begin{abstract}
This case study investigates how well secondary preservice teachers are prepared to use technology in teaching in China. The study focuses on a teacher education program that is a representative of many of those in mid-sized Chinese universities. It examines participants' experiences with, perspectives of, and expectations about the use of technology and the training they are receiving in this area. Data collected through survey and interviews indicate that research participants have similar perspectives regarding the use of technology in teaching and the integration of technology in teacher education as their counterparts elsewhere. They reported an overall low level of ability to use technology and shared some concerns with the technology training they received from the teacher education program.
\end{abstract}

\section{Introduction}

Over the last two decades, the integration of information and communication technology (ICT) into teaching and learning has become an important topic in education. Studies have demonstrated that ICT can enhance teaching and learning outcomes. For example, in science and mathematics education, scholars have documented that the use of ICT can improve students' conceptual understanding, problem solving, and teamwork skills (Culp, Honey \& Mandinach, 2005; Gerban, 1992; Tao \& Gunstone, 1999; Toomey \& Ketterer, 1995; Zhou, Brouwer, Nocente \& Martin, 2005). As a result, many governmental agencies have set up relevant curriculum standards to direct the implementation of technology. A number of non-governmental organisations such as the Society for Information Technology and Teacher Education (SITE) have been founded to promote research and practice in the use of technology in teacher education. Proficiency in using technology has therefore been widely considered as a quality of today's school teachers (Montgomerie \& Irvine, 2001). Naturally, effective and efficient practices of preparing preservice teachers to use technology have become an important research topic.

This study aims to explore a teacher education program in China in regards to its preparing preservice teachers to teach with technology. It focuses on the teacher candidates' experiences with, perspectives of, and expectations about the use of technology and the training they are receiving in this area. 


\section{Literature review}

Since curriculum policy documents provide arguments for introducing ICT in the school setting, schools expect that graduates from teacher education programs have a reasonable knowledge of how to use ICT (Montgomerie \& Irvine, 2001). However, this may not be the case as is noted by Oren, Mioduser and Nachmias (2002), who argue that "most current teachers" preservice preparation and subsequent in-service courses were devised in reference to traditional educational technology and settings... Thus, [the participants in these courses] are not familiar with the processes, interaction patterns, features and possibilities of technology-mediated educational transactions." What compounds this issue even more is that although the students who were born in or after 1982 belong to the "Net Generation," and are accustomed to operating in a digital environment for communication, information gathering and analysis (Oblinger, 2004), they typically lack information literacy skills, and their critical thinking skills are often weak (Oblinger \& Oblinger, 2005). The problem is that students "do not necessarily understand how their use of technology affects their literacy or habits of learning" (Barnes, Marateo \& Ferris, 2007). In other words, "simply incorporating more technology into teaching and learning does not go far enough in ensuring that graduating teacher education students are equipped to deal with the future and social change" (Donnison, 2009, p. 347).

Studies have documented that both pre- and in-service teachers need to be specifically trained in order to integrate ICT in their teaching (Batane, 2004; Jacobsen, Clifford \& Friesen, 2002; Markauskaite, 2007; Mitchem, Wells \& Wells, 2003; Yildirim, 2000) and well developed preservice teachers can take technology leadership once they start to teach in schools (Gao, Wong, Choy \& Wu, 2010). There have been discussions regarding how a teacher education program could effectively prepare teachers to use technology in teaching. In regards to the actual strategies being used to incorporate technology into preservice teacher education, Kay (2006) has recently completed an analysis of sixty-eight refereed journal articles. He identified ten types of operation for technology incorporation including delivering a single technology course, offering mini-workshops, integrating technology with all courses, etc.

Preservice teacher education programs often require teacher candidates to take one technology course taught by an educational technology expert. This type of course is normally designed to assist teacher candidates to develop a variety of technical skills but is insufficient to prepare teacher candidates to teach with technology (Moursund \& Bielefeldt, 1999). As a result, teacher candidates often lack the competence and confidence they need to become comfortable with using technology to teach school subjects (Russell, Bebell, O’Dwyer \& O'Connor, 2003; Schrum, 1999).

Mishra and Koehler (2006) argue that teachers need to develop technological pedagogical content knowledge (TPACK) in order to be successful users of technology in their teaching. Similar to the concept of pedagogical content knowledge (Shulman, 1986), TPACK refers to an integrated understanding of technology, pedagogy, and subject content. This framework suggests that to develop their abilities to teach a subject, teachers must not only grasp the language and artefacts of the subject, and learn essential principles on which learning in this content area is based, but also must learn to structure and enhance learning opportunities for school students. In other words, capable teachers must be able to flexibly incorporate new resources including technology into their knowledge of subject pedagogy in ways that enhance learning. 
There has been an emerging consensus that methods courses provide a natural context for TPACK development, since they are usually designed for teacher candidates to learn how to teach school subjects (Holmes, 2009; Zhou \& Xu, 2011). SITE has promoted this movement by awarding exemplar uses of technology in methods courses. Among the award winners, Bodzin (2005) focused on preservice science teachers' understanding of web-based scientific inquiry. He used the Web-based Inquiry for Learning Science (WBI) instrument to help preservice teachers identify web-based inquiry activities and classify those activities along a continuum from learner-directed to material-directed for each of the essential features of inquiry. Schwarz (2005) helped preservice teachers to understand some of the powerful uses of computer technology in teaching and learning science, and learn how to evaluate pedagogical computer software tools and integrate these tools into their teaching. Hoban (2007) used slow motion animation ("slowmation") to engage preservice teachers in understanding science content knowledge through making models of science concepts and taking digital still photos as the models were manually manipulated in the horizontal plane.

Although the integration of technology with teacher education courses has been written into many teacher education program documents, in reality its implementation is not always successful. Studies in the North American context indicate that, except for individual instructors' attempts as described above, there is a lack of a systematic approach to technology integration. The major factors that contributed to this reality were reported to be the limitation of time and the lack of professional development for faculty members (Zhou \& Xu, 2007). Other factors that influence university instructors' attempts to use technology in teaching include access to technology and technical support (Nantz \& Lundgren, 1998), instructors' beliefs in the effectiveness of technology in enhancing teaching and learning (Adams, 2003; Ebersole \& Vorndam, 2003), and administrative support and incentive policy (Anderson, Varnhagen \& Campbell, 1998).

It seems that effective development of preservice teachers' ICT proficiency is not a straightforward process, but is the one that asks for a careful, multilayered approach. Teo (2008) pointed out that to help teacher candidates build competence and confidence in using technologies, a conducive and non-threatening environment should be provided. Although there is a great deal of research on technology and teacher education, because of the specifics of various teacher education programs, changes in population trends, and rapid advances in technology, there is a constant need for more research about the role of ICT in teacher education programs in specific contexts (Zhang \& Martinovic, 2008).

Although the literature has consistently pointed out that one technology course is inadequate to prepare preservice teachers to teach with technology, it still lacks detailed descriptions and particularly sound evaluation of other alternative approaches for technology incorporation in teacher education (Kay, 2006). Also, the literature needs to provide further information about what ICT skills and knowledge teachers require at schools, and explore preservice teachers' perceptions of ICT and their attitudes toward ICT integration into curriculum (Murphy, 2000). These attitudes and perceptions are instrumental to how future teachers will use ICT in their teaching (Sasseville, 2004). 


\section{Research context}

Like those of many other countries, the Chinese government has realised the significance of educational technology. In December 1999, China Ministry of Education set up the China Educational Technology in Higher Education Committee to promote technology adoption in post-secondary institutions. With regard to schools, it launched a project of Connecting Every School in 2000. This project aims to connect $90 \%$ of schools onto the Internet so that their teachers and students can have access to high quality online educational resources within the following five to ten years. In order to guide the practice of using technology in schools, the Ministry released a bundle of educational technology standards for teachers, administrators, and facilitators in 2002, just a few years after the International Society for Technology in Education (ISTE) first developed the National Educational Technology Standards for students and teachers at the end of last century.

As a result of these government campaigns, the use of ICT in classrooms has become a well-known requirement for teachers (Miao, 2007). Different models have been used for teacher education and teacher professional development ( $\mathrm{Zhu} \& \mathrm{Gu}, 2007$ ). However, due to various reasons, the introduction of ICT in education settings has been experiencing challenges (Li, n.d.). ICT utilization in Chinese educational system shares some similar challenges faced in other countries, but some context-specific problems exist as well. While most school administrators in China are interested in increasing ICT application in teaching, few of them have taken specific measures to promote it. There are not enough teachers who specialize in ICT use (China Ministry of Education, 2008). Another major cause of such challenges could be the contradictions between different teaching systems and pedagogies ( $\mathrm{Hu} \& \mathrm{Webb}, 2009$ ). In order to make effective use of ICT for teaching and learning, a better understanding of ICT and its use in the Chinese educational context is required (Zhou, 2005).

There is a lack of studies on teacher preparation for the use of ICT in China. Documents we found on ICT and teacher education are mostly descriptions of policies regarding ICT use in schools and the programs are usually for in-service teacher training rather than preservice teacher education. One exception is a survey study by Song et al. (2005). This study reports that as low as $10 \%$ of participating pre- and inservice teachers considered themselves "fluent" on their basic computer skills. They reported that although pre- and in-service teachers were required to take computer literacy courses or training programs, there were no specific requirements on integrating ICT into teaching and learning.

\section{Methodology}

In China, secondary teacher education takes place in a format in which preservice teachers are registered in subject departments such as physics, chemistry, mathematics, and so on. Instructors from the Faculty of Education are dispatched to subject departments to teach educational courses, particularly the education foundation courses. In most cases, the subject methods courses are taught by faculty members from subject departments, not by those from the Faculty of Education.

This study was conducted in a comprehensive university in the east part of China. The university has over 26,000 full time undergraduate students, and about a half of the enrolment was in its teacher education program. Like many Chinese universities, 
secondary school teacher candidates are registered in different subject departments while those in the elementary teacher education program are housed in the Faculty of Education. The university has a School of Media and Communication Technology which offers a compulsory educational technology course to all preservice teachers. The course is taught in each individual department and each class enrols only students from the same department. This study focused on the junior and senior preservice teachers who had already taken the technology course. Data collection was carried out in June of 2008 and 2009, the last month of the academic year in Chinese universities.

\section{Research design and research questions}

A case study can be conducted to examine the details of a setting, subject, or particular event (Yin, 2009) with the aim of providing "descriptions of a case, a group, a situation, or an event" (Krathwohl, 1998, p. 26). This study explored the practices of a Chinese teacher education program in terms of ICT incorporation. The following two research questions were used as guidelines for the study:

1. What are the preservice teachers' perspectives of and confidence with the use of ICT in teaching and learning?

2. What are their experiences and suggestions regarding ICT training for teacher education?

\section{Participants and data collection}

The study employed mixed methods including survey, interview, and focus group. The survey questionnaire was developed based on the instruments we used before for our previous and related studies (Lynblinskaya \& Zhou, 2008; Zhang \& Martinovic, 2008; Zhou, Varnhagen, Sears, Kasprzak \& Shervey, 2007). It has three sections. The first section collects demographic information including gender, age, major, location of high schools they graduated from, ownership of computers, technology training before taking the educational technology course, etc. The second section uses Likert style questions to assess participants' confidence in using technology in their own learning and future teaching, their perspectives of the use of technology in teaching, preferred model of technology integration with teacher education, and preferred content coverage of the technology course. The third section consists of open-ended questions soliciting participant's suggestions and comments regarding the technology course, models of technology integration in a teacher education program, and the university's ICT facilities. The survey was examined and re-examined by three researchers to avoid vague meeting. It was piloted with five undergraduate students. Changes were made based on the feedback from the pilot. In order to gain a deeper understanding of preservice teachers' perspectives upon and experiences with technology training, interviews and focus groups were conducted.

The study conducted in 2008 had a small scale, being administered by the first author to only four classes: two classes from science-related Faculties and the other two from social science related Faculties. In addition, the survey was administered to the Faculty of Education students who came to a public lecture. All students in the four selected classes filled out and returned the survey questionnaire. However, this paper only focuses on secondary school preservice teachers so that the survey responses from the Faculty of Education students were not included here. Three pair interviews were conducted by the same researcher. One pair of interviewees was from the Department of Physics (one male and one female), one from the Department of Music and Arts 
(two females), and one from the Department of Chinese (one male and one female). In 2009, the survey was slightly revised (adding one more demographic question) and distributed by the third author to 12 classes with 7 from science-related Faculties and 5 from social science Faculties. All students returned their surveys. Three focus groups with a total of 16 participants were conducted by the first author. Two focus groups had 6 (three males and three females) and 3 (two males and one female) science students respectively, and the third involved 7 social science students (three males and four females). Each pair interview or focus group discussion lasted about 90 minutes and was audio recorded.

Surveys and interviews were conducted in Chinese. Survey data were compiled by a graduate research assistant who was fluent in both Chinese and English. Interview recordings were transcribed by the same assistant. The survey data were analysed with SPSS for both descriptive and inferential purposes. The descriptive analysis provides information regarding response distributions for each topic that the survey covered. The inferential analysis investigated how the variables of the survey were related to one another and drew some conclusions that may apply to the population going beyond the sample itself. The interview analysis started with an open coding technique followed by themes identification. Themes emerged from the coding around topics such as participants' experience with the technology course, their perspectives about technology training in teacher education, and expectations for changes to the teacher education program.

\section{Survey findings}

A total of 390 students participated in the survey. Approximately 65\% of participants were females and 35\% males. Nearly $4 \%$ of participants were 20 years old or younger, 77\% between 21 and 23, and 19\% older than 23. Approximately 52\% were enrolled in Science or Engineering related departments and $48 \%$ in Social Science, Humanities and Arts. In regard to the locations of high schools they graduated from, $16 \%$ graduated from high schools located in countryside or township centres, $62 \%$ in small cities, and $22 \%$ in medium-sized or big cities.

Regarding computer ownership, approximately $35 \%$ of participants had computers in their households and $65 \%$ did not; $30 \%$ had their own computers and $70 \%$ did not. Approximately $78 \%$ had taken computer courses before they attended the university and 22\% had not. Participants reported that computer courses were their primary route to gaining computer knowledge (70\%), 20\% learned computer knowledge mainly through self-directed learning, and 10\% reported to have learned from friends or other individuals.

In response to the question about their ability to use technology, 16\% chose "I know little about technology," 37\% chose "I am learning how to use technology," $28 \%$ chose "I have started to understand how to use technology," $11 \%$ chose "I am proficient in using technology," and 8\% chose "I am proficient in using technology in my learning and teaching." Regarding their self confidence in using technology, 8\% felt nervous and avoided using technology, $27 \%$ were often intimidated when they tried to use it, $48 \%$ were gradually getting confident with technology, and $17 \%$ felt very confident to use technology. When asked about their ability in using technology in teaching, $17 \%$ did not know how to use technology in teaching, $74 \%$ knew how to use technology in teaching, and only 9\% thought they were proficient in using technology in teaching (Table 1). 
Table 1: Ability and confidence with the use of technology ( $\mathrm{N}=390)$

\begin{tabular}{|l|l|c|}
\hline \multicolumn{1}{|c|}{ Question } & \multicolumn{1}{c|}{ Choice } & Response (\%) \\
\hline $\begin{array}{l}\text { Ability to use } \\
\text { technology in } \\
\text { general }\end{array}$ & I know little about technology & 16 \\
\cline { 2 - 3 } & I am learning how to use technology & 37 \\
\cline { 2 - 3 } & I have started to understand how to use technology & 11 \\
\cline { 2 - 3 } & I am proficient in using technology & 8 \\
\cline { 2 - 3 } & I am proficient in using technology in my learning and teaching & 27 \\
\hline $\begin{array}{l}\text { Confidence } \\
\text { with the use of } \\
\text { technology }\end{array}$ & I feel nervous and avoid using technology & 48 \\
\cline { 2 - 3 } & I was often intimated when I tried to use technology & 17 \\
\cline { 2 - 3 } & I am gradually getting confident with technology & 74 \\
\hline $\begin{array}{l}\text { Ability to use } \\
\text { technology in } \\
\text { teaching }\end{array}$ & I feel very confident to use technology & 9 \\
\cline { 2 - 3 } & I know how to use technology in teaching & \\
\cline { 2 - 3 }
\end{tabular}

Regarding their perspectives upon technology, 54\% agreed and 34\% strongly agreed that "Technology is a useful tool for school teaching." Approximately 51\% agreed and $30 \%$ strongly agreed that "All teachers should learn how to use technology in teaching," and 53\% agreed and 24\% strongly agreed that "It is important for school students to learn technology." (Table 2)

Table 2: Perspectives of the use of technology $(\mathrm{N}=390)$

\begin{tabular}{|l|c|c|c|c|c|}
\hline \multicolumn{1}{|c|}{ Question } & \multicolumn{5}{c|}{ Response (\%) } \\
\cline { 2 - 6 } & $\begin{array}{l}\text { Strongly } \\
\text { disagree }\end{array}$ & Disagree & Neutral & Agree & $\begin{array}{c}\text { Strongly } \\
\text { agree }\end{array}$ \\
\hline $\begin{array}{l}\text { Technology is a useful tool for school } \\
\text { teaching }\end{array}$ & 2 & 1 & 9 & 54 & 34 \\
\hline $\begin{array}{l}\text { All teachers should learn how to use } \\
\text { technology in teaching }\end{array}$ & 2 & 1 & 16 & 51 & 30 \\
\hline $\begin{array}{l}\text { It is important for school students to learn } \\
\text { technology }\end{array}$ & 1 & 3 & 19 & 53 & 24 \\
\hline
\end{tabular}

Three scenarios were described to participants regarding how to incorporate technology in teacher education: (1) one technology course only, (2) technology is integrated in the methods courses, and (3) a blended model of these two options. Approximately $86 \%$ participants chose the blended model as the best curriculum design, while $6 \%$ chose model (1) and $8 \%$ model (2).

Participants were asked to choose the knowledge domains the technology course should cover. Approximately 53\% thought that the course should cover the basic knowledge of computer hardware, $87 \%$ thought that it should cover the use of software applications, and $68 \%$ believed that it should cover theoretical knowledge about the use of technology in teaching.

When asked about their suggestions for improvements the university should undertake in technology, 42\% suggested updating hardware, 52\% suggested updating software, $76 \%$ suggested increasing the network speed, and 52\% suggested increasing access to technology by purchasing more computers, extending computer lab hours, etc.

In order to compare the different perspectives between male and female participants, the three measures mentioned above in regards to participants' perspectives upon the 
use of technology were combined into one variable. The result of a t-test on this new variable indicated that there was statistically significant gender difference $(p<.05)$ (Table 3). Female participants had a more positive perspective toward the use of technology. There was no significant perspective difference between science participants versus social science participants, home computer owners versus those who did not have a computer at home, and personal computer owners versus those who did not have a personal computer.

Table 3: Different perspectives of technology use between males and females

\begin{tabular}{|c|c|c|c|c|c|}
\hline Variable & Group & Number of cases & Mean & Standard deviation & $\mathrm{t}$-test results \\
\hline \multirow{2}{*}{$\begin{array}{l}\text { Perspectives upon using } \\
\text { technology }\end{array}$} & Female & 246 & 12.34 & 1.93 & $\mathrm{t}=1.959$, \\
\cline { 2 - 6 } & Male & 137 & 11.93 & 1.98 & $\mathrm{p}<.05$ \\
\hline
\end{tabular}

In terms of computer ownership, Chi-square test results indicate that there was a significant difference between participants graduated from rural and urban high schools (Table $4, \mathrm{p}<0.000$ ). Approximately $14 \%$ of graduates from countryside or township centre high schools reported an ownership of a household computer, while $35 \%$ of graduates from small city high schools and $48 \%$ from medium-sized or big city high schools owned household computers. A significant location difference existed for personal computer ownership as well (Table 5, p <.01).

Table 4: Location of high school vs. home computer ownership

\begin{tabular}{|c|c|c|c|c|c|c|}
\hline \multirow{2}{*}{\multicolumn{4}{|c|}{ Cross tabulation }} & \multicolumn{2}{|c|}{$\begin{array}{c}\text { Home computer } \\
\text { ownership }\end{array}$} & \multirow[t]{2}{*}{ Total } \\
\hline & & & & Yes & $\mathrm{No}$ & \\
\hline \multirow{3}{*}{$\begin{array}{l}\text { Location of high } \\
\text { school }\end{array}$} & \multicolumn{3}{|c|}{ Countryside or township centre } & 9 & 54 & 63 \\
\hline & \multicolumn{3}{|c|}{ Small city } & 83 & 156 & 239 \\
\hline & \multicolumn{3}{|c|}{ Medium-sized or big city } & 41 & 44 & 85 \\
\hline \multicolumn{4}{|r|}{ Total } & 133 & 254 & 387 \\
\hline \multicolumn{2}{|c|}{ Chi-square tests } & Value & $\mathrm{df}$ & \multicolumn{3}{|c|}{ Asymp. sig. (2-sided) } \\
\hline \multicolumn{2}{|c|}{ Pearson chi-square } & 18.525 & 2 & \multicolumn{3}{|c|}{.000} \\
\hline \multicolumn{2}{|l|}{ Likelihood ratio } & 19.951 & 2 & \multicolumn{3}{|c|}{.000} \\
\hline \multicolumn{2}{|c|}{ Linear-by-linear association } & 17.998 & 1 & \multicolumn{3}{|c|}{.000} \\
\hline \multicolumn{2}{|l|}{ No. of valid cases } & 387 & & & & \\
\hline
\end{tabular}

Table 5: Location of high school vs. personal computer ownership

\begin{tabular}{|c|c|c|c|c|c|c|}
\hline \multirow{2}{*}{\multicolumn{4}{|c|}{ Crosstabulation }} & \multicolumn{2}{|c|}{$\begin{array}{l}\text { Personal computer } \\
\text { ownership }\end{array}$} & \multirow{3}{*}{$\begin{array}{c}\text { Total } \\
62\end{array}$} \\
\hline & & & & Yes & No & \\
\hline \multirow{3}{*}{$\begin{array}{l}\text { Location of high } \\
\text { school }\end{array}$} & \multicolumn{3}{|c|}{ Countryside or township centre } & 12 & 50 & \\
\hline & \multicolumn{3}{|c|}{ Small city } & 67 & 170 & 237 \\
\hline & \multicolumn{3}{|c|}{ Medium-sized or big city } & 35 & 49 & 84 \\
\hline \multirow{2}{*}{\multicolumn{4}{|c|}{ Chi-square tests }} & 114 & 269 & 383 \\
\hline \multirow{2}{*}{\multicolumn{2}{|c|}{$\begin{array}{l}\text { Chi-square tests } \\
\text { Pearson chi-square }\end{array}$}} & Value & $\mathrm{df}$ & \multicolumn{3}{|c|}{ Asymp. sig. (2-sided) } \\
\hline & & 9.159 & 2 & \multicolumn{3}{|c|}{.010} \\
\hline \multicolumn{2}{|l|}{ Likelihood ratio } & 9.098 & 2 & \multicolumn{3}{|c|}{.011} \\
\hline \multicolumn{2}{|c|}{ Linear-by-linear association } & 8.922 & 1 & \multicolumn{3}{|c|}{.003} \\
\hline \multicolumn{2}{|l|}{ No. of valid cases } & 383 & & & & \\
\hline
\end{tabular}




\title{
Interview findings
}

\section{Experiences with the technology course}

Interview participants were asked to reflect on their experiences with the educational technology course. A majority of them reported that they did not take it as their favourite course. The course had two discrete components, lecture and lab. They disliked the separation of these two parts. The lab was supposed to provide preservice teachers with opportunity to practise what was lectured, however it was often scheduled one or two weeks after the lecture. Participants complained that such time gaps made quick feedback impossible. They often forgot what they heard in the lecture and what they wanted to ask about by the time they got in the lab. One participant pointed out:

\begin{abstract}
The main issue with this course was the disconnection between lectures and labs. We did not have the opportunity to practise what we learned from the lecture until one or two weeks afterwards. We forgot what the instructor taught. And often, you had questions during the lecture and wanted to figure them out during the practice. But you had forgotten these questions by the time you entered the lab.
\end{abstract}

Even if they remembered the lecture content and their questions, the limited lab resource was a challenge for participants. They reported that oftentimes several teacher candidates had to share one computer. And as there was no lab assistant available, the whole class had to rely on one instructor for assistance. It was not possible for all teacher candidates to get help in the lab.

Participants said they did not like listening to the instructor "talking about" how to use software or how to operate equipment without any demonstrations. The course covered many technology tools, but there was very little practice. In the final exam, students were required to memorise the operation procedures described in the textbook. Participants' concerns about the technology course were nicely summarised in the following response:

\begin{abstract}
Most of the time, the instructor described [italics added] how to use software and operate equipment. We rarely have the opportunity to practice. The lecture did not use demonstration. We often found some technical terminologies strange and the lectures hard to understand. In addition, the instructor did not have the time to help every student in lab sessions. This was mainly because of the large class size in one lab. As a result, we had many questions, but we could not get them answered. Eventually we lost motivation and interest.
\end{abstract}

The lack of opportunities to practice with the technology did not happen only in the technology course. Participants reported that their desire to use technology during teaching practicum often failed because most schools they were placed in did not have adequate access to technology. One participant described this challenge in his response:

We only listened to the lecture and lacked practice. This was the real challenge of this course. In addition, we did not have opportunity to use technology during the teaching practicum either because schools often did not have the equipment. The textbook knowledge has never been put into practice. As new teachers, we all wanted to use technology during our teaching practicum. However, this wish was not realised because of such limitations. 
Another participant added that they had only three weeks of teaching practice in schools. This short period of time made it hard to plan the use of technology.

An additional reason for participants' disliking the course was because it was a foundation course. In China, almost in any higher education institutions, students often perceive foundation courses as of less value than their subject courses. Like other foundation courses, this course was reported to have loose requirements and the associated exam was easy. Students often took it as an easy course. One participant commented:

This course was a foundation course. We did not put lots of values in it... It covered a lot of content but relatively it was assigned less class hours. In addition, the instructor was easy going with light requirement load. The exam was easy too. Most students therefore do not take the course very seriously.

Regarding the content of the course, all participants believed that it was important to learn how to use software in teaching. The theoretical discussions about the use of technology were considered valuable as well. However, regarding hardware knowledge, participants had different opinions. Most interview and focus group participants believed "[hardware knowledge] is not important. The main purpose of this course is to teach us how to apply technology in teaching." However, one participant from the Department of Physics stated that the instructor should provide introduction to hardware knowledge, even if it was just some basic knowledge:

I think what we learned from the technology course was too shallow. We are physics major students. We wanted to know the principles of technologies rather than only how to use them. I think in our future teaching, we will inevitably run into situations where equipment needs trouble shooting. If we have such knowledge, we can solve the problem by ourselves.

To summarise participants' experiences with and suggestions for the technology course, we quote the following participant's statement:

I think the technology course did not generate good results because it was not taught in a way that had theory and practice connected. Students were not clear about the purpose and significance of using technology tools... Lecturing made students lose their initial interest in the subject. If the university wants to improve the quality of this course, the theory should be connected with practice ... [ideally] students first learn how to use technology tools and have a good foundation of technology knowledge, and then an instructor who is good at both subject pedagogy and technology demonstrates how to apply technology to lesson planning and teaching.

\section{Perspectives on technology incorporation with teacher education}

All participants believed that a teacher education program should develop teacher candidates' technology proficiency. When asked about their preferred model of technology training for teacher education, most participants indicated that the third model [one technology course plus technology integration with methods courses] is most ideal. They believed that technology incorporation in teacher education should emphasise the connection between theory and practice:

I think that a technology course and technology integration with methods courses are both necessary. The technology course teaches us how to use technology. If we had the chance to use technology in the methods courses, it would be the best. 
Participants also realised the difficulty with the implementation of this model: credit limitation. There was not enough time in the program to be allocated to technology. One participant also mentioned his concerns about the integration of technology with methods courses. He thought technology would not fit into methods courses. Therefore he voted for an independent technology course:

I think educational technology should be offered as an independent course. The methods course we took focused on discussing the theories and perspectives of subject teaching. An addition of technology to this course doesn't seem to fit. It will make the course content less consistent. The third approach [combination of technology course and technology integration] should have the best results. However, it will face great barriers in implementing because we don't have enough time allocated to technology. Relatively speaking, the model of one technology course is most practical.

When asked why he thought technology would not fit into the methods course, this participant replied, "The methods course discussed about the overall procedure of instructional planning and the approaches to managing the class. The instructor did not actually discuss how to teach any particular topics, let alone demonstrating teaching."

Some participants believed that the second model [integration with methods courses] is the best model. One participant commented: "For the purpose of learning how to teach physics better, I believe that the methods course is the best place to learn ICT." However, she aired her concerns right away. "But we may only learn the partial function of a technology tool and lack a comprehensive knowledge about it." Another participant was much more optimistic about this approach:

I agree with the idea of learning educational technology in the methods course. This will save time and is practical as well. I feel I will have great interest in learning technology that way because I can see the usefulness of technology. Even though the university does not offer a technology course, I will be motivated to learn it by myself.

One participant voted for the current status quo and allowed the disconnectedness between the technology course and methods course:

I believe the technology course and methods course should both exist. The methods course is important. It covers much content. I learned a lot from it. The time for this course is limited so there is not enough time to add a technology component. The technology course is a practical course and it requires lots of time to learn the content. In addition, I think if technology is added to the methods course, it will present a challenge to instructors.

\section{Perspectives on social software}

The technology course did not cover social software such as blogs, QQ (popular online communication software in China), and MSN. Participants' perspectives on these technologies were largely based on their personal experiences. One participant believed that "Blog is used for personal purpose only and did not have connection with teaching." Another participant saw the potential of blogs to "enhance the communication between the teacher and students, but cannot help much with classroom instruction."

When asked whether the social software could be used for the purpose of communication among students, participants provided positive attitudes. But they 
added that "these technologies can only be used in cities because urban families possess computers. It is not realistic to promote these technologies in rural areas."

Many participants realised the potential of social software for professional development. They believed that "the online forum can greatly help professional development."; "These online forums can broaden our visions and promote different ways of thinking." Some participants stressed the challenges of online forums in terms of information selection: "The information posted in the forums is not always true and reliable. We need to reflect on whether others' approaches are applicable to our own contexts." One participant reported her concern of being attacked by forum subscribers. She stated:

I don't post my opinions without careful thinking because I am afraid of being attacked by other forum users. I hesitated to present my opinions or viewpoints at the beginning. However, I gradually noticed that others' critiques are useful for my progress. You cannot be only a forum consumer. You need to be a contributor.

Another participant noticed the value of information sharing through blogs. He stated that teachers could publish learning materials for students to download and teachers could also share their teaching materials through a blog. However, he added, "The information sharing has limitations because there is competition between teachers. In addition, one teacher's approach cannot be rigidly copied by another teacher." When asked what he would like to share through internet, this participant said he would like to share the materials that were useful for students, "but I don't easily post my opinion on academic debates."

\section{Challenges for using technology in teaching}

Participants were asked about the challenges they anticipated to have with the use of technology at the beginning of their teaching careers. Many indicated their low confidence in implementing technology. They envisioned that they would need to spend lots of time in the future to learn technology. One participant responded to this question using a popular Chinese statement: "the strongest enemy is self." What she referred to entails the need to motivate self and find time to learn technology. This concern even pushed some participants to think of giving up on technology:

I also think my skills in technology are not mature. If I really need technology to teach in the future, I am afraid that I will need to spend lots of time in preparing lessons. For this reason, I feel more comfortable using traditional teaching approaches. Or, I will only try technology in one or two subjects, and leave other subjects free of technology use.

Another participant saw a different challenge. He stated that learning technology through self teaching was not a hard thing to do. He believed that support from the school principal and coworkers was most important. "If the school has adequate equipment and its administrators encourage teachers to explore new instructional approaches, I am willing to use technology more." Another participant, who had already signed a contract for a teaching position commencing in September, provided a wonderful statement regarding this question:

For this question [about challenges], the first thing came to my mind is the word of "adaptation." Being a new graduate, I will soon change from a student to a teacher. I need to face the generation gap between my students and me. They were born in the 1990 s or later so there must be some differences between us in terms of values and 
personalities. My biggest challenge in the use of technology is to choose instructional approaches that best meet students' needs and interests. Because I don't have experiences, I do not know which kinds of technology are effective. To deal with this challenge, I need to try out various kinds of technology... Of course, this needs strong belief and courage as it could be risky to use technology. If the use is appropriate, students will benefit; however if the use is inappropriate, my classes will fall behind other classes. But I have the courage to try.

\section{Discussion}

Computer ownership varied among research participants. Participants from urban areas had a significantly higher rate of computer ownership than those from rural and suburban areas. This survey finding was consistent with focus group participants' comment that social software could be used to promote student communication in cities, but it was not realistic in the countryside because of the lack of access to technology. The overall rate of household or personal computer ownership was quite low. Only about one third of participants had household computers and less than one third had personal computers, be they desktops or laptops.

Similarly, the university may fall behind in terms of ICT facilities. Over forty percent of participants wanted the university to update its hardware, and more than fifty percent suggested the university increase the number of computers and labs. Over half of the participants wanted the software to be updated and approximately seventy-six percent saw a need for a higher-speed campus network. The inadequate access to technology was also reflected by the frustrations expressed by focus group participants with the limited access to computer labs.

Close to ninety percent of participants agreed that technology is a useful tool for teaching, over eighty percent believed that school teachers need to learn how to use technology in teaching, and seventy-seven percent considered it was important for school students to learn technology. However, these positive perspectives of technology did not come with high ability and confidence to use it. Only eleven percent self reported to be proficient in using technology and less than seventeen percent felt confident with the use of technology. Although a majority of participants knew technology could be a useful tool for teaching, only nine percent felt proficient to actually use technology in teaching. In addition, the lack of technology preparation for teaching was frequently mentioned by focus group participants.

Consistent with the findings of Moursund and Bielefeldt (1999), participants were apparently not yet well prepared to use technology in teaching at the time this study was conducted, although they had taken the required technology course. This might be due partially to the way the technology course was taught. The instructors were dispatched from the School of Media and Communication Technology to teach the technology course in subject departments, with one instructor usually covering more than one department. This centralised model makes it very likely that the course was focused on the training of technical skills rather than technology-mediated subject pedagogy. In addition, the course often took place in a "lecture + lab" format. During the interviews, participants reported that the instructor taught how to use a computer application in the lecture room, but the hands-on practice was often scheduled a couple of weeks later in the computer lab. This arrangement of location and time created barriers for participants wanting to learn how to use technology tools. Interview participants clearly stated that they wanted to practise what they learned in 
class and get answers to the questions they had during the lecture, however they often forgot what they learned and what their questions were when they entered the lab two weeks after the lecture was given. Each class usually had over thirty students and there was no teaching assistant available. Many questions were poured onto the instructor at the same time. Students who could not get an opportunity to reach the instructor would surf the Internet for topics that were more often than not off the learning task.

Participants realised the importance of the connection between technology and subject pedagogy. Most of them thought a teacher education program should integrate technology with methods courses in addition to offering a technology course, although this may encounter some difficulty with implementation, due to the limited time and lack of faculty members who have expertise in both educational technology and subject pedagogy. Close to ninety percent of participants believed a blended model of technology education was more appropriate than either one technology course only or technology integration with methods courses only. They suggested that the technology course should cover sound theoretical knowledge about the use of technology in teaching and that the methods course should bring technology into subject pedagogy. No matter what the curriculum looks like, participants voted for a way of connecting theory and practice in technology training. Participants suggested that the technology course should increase the portion of practice and the methods course should go beyond theory into modeling topic teaching including using technology.

This study confirms the statement of Zhang and Martinovic (2008) on the lag in technology courses compared with the advances in this field. In this study, the technology course was reported to cover traditional technology tools such as PowerPoint, Flash, camera, etc, but left out recently developed social software, which has great potential to enhance teaching and learning (Bryant, 2007; McLoughlin \& Lee, 2008). It is important for ICT education to keep up with current trends. Otherwise, preservice teachers would miss opportunities to take advantage of new technologies that could offer great pedagogical potential.

\section{Concluding remarks}

This study found that the research participants were not well prepared to use technology in teaching by their teacher education program. They had similar perspectives regarding the use of technology in teaching, and their suggestions were not much different from what has been discussed in other countries regarding how technology should be integrated in teacher education. The teacher education program should re-configure its technology course to address the participants' concerns. A better way of blending the lecture and lab components is necessary for teacher candidates to more effectively acquire technology skills. An examination of its teacher education curriculum, particularly methods courses, needs to be done in order to develop a better connection between theory and practice about the use of technology in teaching. How does the technology course address pedagogy? How does the methods course incorporate technology? These are some of the questions deserving answers.

Nevetheless, the teacher education program in this case study has its unique characteristics. The educational technology course is offered by instructors from a technology unit to teacher candidates who are registered in subject departments. In 
this technology-centralised and teacher education-distributed environment, solutions to these questions involve more complexity compared with teacher education programs in other countries where all teacher education students and courses are housed in the Faculty of Education. This study has only started a small step but will hopefully draw more attention to this research topic.

\section{References}

Adams, N. (2003). Educational computing concerns of post secondary faculty. Journal of Research on Technology in Education, 34(3), 285-303. http:/ / www.iste.org/Store/Product.aspx?ID=1866

Anderson, T., Varnhagen, S. \& Campbell, K. (1998). Faculty adoption of teaching and learning technologies: Contrasting earlier adopters and mainstream faculty. The Canadian Journal of Higher Education, 28(2/3), 71-98.

http: / / auspace.athabascau.ca:8080/dspace/handle/2149/1079

Barnes, K., Marateo, R. C. \& Ferris, S. P. (2007). Teaching and learning with the net generation. Innovate, 3(4). http:/ / www.innovateonline.info/pdf/vol3_issue4/Teaching_and_Learning_ with_the_Net_Generation.pdf

Batane, T. (2004). Inservice teacher training and technology: A case of Botswana. Journal of Technology and Teacher Education, 12(3), 387-410. http: / / www.editlib.org/p/11428

Bodzin, A. M. (2005). Implementing web-based scientific inquiry in preservice science methods courses. Contemporary Issues in Technology and Teacher Education, 5(1). http: / / www.citejournal.org/vol5/iss1/general/article1.cfm

Bryant, L. (2007). Emerging trends in social software for education. In British Educational Communications and Technology Agency Emerging Technologies for Learning: Volume 2. Coventry: Becta. [verified 9 Sep 2011] http: / / webarchive.nationalarchives.gov.uk/20101102103654/http: / / research.becta.org.uk/ upload-dir/downloads/page_documents/research/emerging_technologies07_chapter1.pdf

China Ministry of Education (2008, February 25). The second Ministry of Education 2008 regular news conference: The utilization of the Rural Distance Education Project equipment (in Chinese). [date viewed not given; not found 9 Sep 2011] http: / / www.moe.gov.cn/ edoas / website18/88/info1203994285182188.htm

Culp, K., Honey, M. \& Mandinach, E. (2005). A retrospective on twenty years of education technology policy. Journal of Educational Computing Research, 32(3), 279-307. http: / / dx.doi.org/ 10.2190/7W71-QVT2-PAP2-UDX7

Donnison, S. (2009). Discourses in conflict: The relationship between Gen Y pre-service teachers, digital technologies and lifelong learning. Australasian Journal of Educational Technology, 25(3), 336-350. http: / / www.ascilite.org.au / ajet/ ajet25/ donnison.html

Ebersole, S. \& Vorndam, M. (2003). Adoption of computer-based instructional methodologies: A case study. International Journal of E-Learning, 2(2), 15-20. http: / / www.editlib.org/p/18874

Gao, P., Wong, A. F. L., Choy, D. \& Wu. J. (2010). Developing leadership potential for technology integration: Perspectives of three beginning teachers. Australasian Journal of Educational Technology, 26(5), 643-658. http:/ / www.ascilite.org.au/ajet/ ajet26/gao.html

Gerban, O. (1992). Effects of computer simulations and problem solving approaches on high school students. Journal of Educational Research, 86(1), 5-10. http: / / www.jstor.org/ stable/ 27540507 
Hoban, G. F. (2007). Using slowmation to engage preservice elementary teachers in understanding science content knowledge. Contemporary Issues in Technology and Teacher Education, 7(2). http:/ / www.citejournal.org/vol7/iss2/general/article2.cfm

Holmes, K. (2009). Planning to teach with digital tools: Introducing the interactive whiteboard to pre-service secondary mathematics teachers. Australasian Journal of Educational Technology, 25(3), 351-365. http:/ / www.ascilite.org.au/ajet/ajet25/holmes.html

Hu, L. \& Webb, M. (2009). Integrating ICT to higher education in China: From the perspective of activity theory. Education and Information Technologies, 14(2), 143-161. http: / / dx.doi.org/10.1007/ s10639-008-9084-6

Jacobsen, M., Clifford, P. \& Friesen, S. (2002). Preparing teachers for technology integration: Creating a culture of inquiry in the context of use. Contemporary Issues in Technology and Teacher Education, 2(3), 363-388.

http: / / www.citejournal.org/vol2/iss3/currentpractice/article2.cfm

Kay, R. H. (2006). Evaluating strategies used to incorporate technology into pre-service education: A review of the literature. Journal of Research on Technology in Education, 38(4), 383408. http:/ / www.eric.ed.gov / ERICWebPortal/ contentdelivery/ servlet/ERICServlet?accno $=\mathrm{EJ} 768720$

Krathwohl, D. (1998). Methods of educational and social science research: An integrated approach (2nd ed.). New York: Addison-Wesley Educational Publications, Inc.

Li, C. (n.d.). China: ICT use in education. UNESCO meta-survey on the use of technologies in education. [verified 9 Sep 2011]

http: / / www.unescobkk.org/fileadmin/user_upload/ict/Metasurvey/CHINA.PDF

Lynblinskaya, I. \& Zhou, G. (2008). Integrating graphing calculators and probeware into science methods courses: Impacts on preservice elementary teachers' confidence and perspectives on technology for learning and teaching. Journal of Computers in Mathematics and Science Teaching, 28(2), 163-182. http:/ / www.editlib.org/p/ 24194

Markauskaite, L. (2007). Exploring the structure of trainee teachers' ICT literacy: The main components of and relationships between, general cognitive and technical capabilities. Educational Technology Research and Development, 55(6), 547-572. http: / / dx.doi.org/ 10.1007/s11423-007-9043-8

McLoughlin, C. \& Lee, M. (2008). Future learning landscapes: Transforming pedagogy through social software. Innovate: Journal of Online Education, 4(5). Retrieved from http: / / innovateonline.info/pdf/vol4_issue5/Future_Learning_Landscapes_Transforming_Pedagogy_through_Social_Software.pdf

Miao, F. (2007). ICT in teacher education: Case studies from the Asia-Pacific region. Bangkok, Thailand: UNESCO. http: / / unesdoc.unesco.org/images/0015/001567/ 156757e.pdf

Mishra, P. \& Koehler, M. J. (2006). Technological pedagogical content knowledge: A framework for teacher knowledge. Teachers College Record, 108(6), 1017-1054. http: / / www.tcrecord.org/ content.asp?contentid=12516

Mitchem, K., Wells, D. L. \& Wells, J. G. (2003). Effective integration of instructional technologies (IT): Evaluating professional development and instructional change. Journal of Technology and Teacher Education, 11(3), 397-414. http: / / www.editlib.org/p/14612

Montgomerie, C. \& Irvine, V. (2001). Computer skill requirements for new and existing teachers: Implications for policy and practice. Journal of Teaching $\mathcal{E}$ Learning, 1(1), 43-55.

http: / / ojs.uwindsor.ca/ojs/leddy/index.php/JTL/article/download/114/149 
Moursand, D. \& Bielefeldt, T. (1999). Will new teachers be prepared to teach in a digital age? A national survey on information technology in teacher education. Santa Monica, CA: Milken Exchange on Educational Technology. http:/ / www.eric.ed.gov/ERICWebPortal/ content delivery / servlet/ERICServlet?accno=ED428072

Murphy, C. (2000). Effective use of ICT by student teachers: Is it improving? Proceedings of the Society for Information Technology \& Teacher Education 2000 International Conference (pp. 16561661). San Diego. http:/ / www.eric.ed.gov/ERICWebPortal/ contentdelivery/servlet/ERIC Servlet?accno=ED444549

Nantz, K. \& Lundgren, T. D. (1998). Lecturing with technology. College Teaching, 46(2), 53-56. http: / / dx.doi.org/10.1080/87567559809596235

Oblinger, D. (2004). The next generation of educational engagement. Journal of Interactive Media in Education, 8. http: / / www-jime.open.ac.uk/2004/8/oblinger-2004-8.pdf

Oblinger, D. C. \& Oblinger, J. L. (Eds.) (2005). Educating the Net Generation. Washington DC: EDUCAUSE. http:/ / www.educause.edu/books/educatingthenetgen/

Oren, A., Mioduser, D. \& Nachmias, R. (2002). The development of social climate in virtual learning discussion groups. International Review of Research in Open and Distance Learning, 3(1). http: / / www.irrodl.org/index.php/irrodl/article/view/80/155

Russell, M., Bebell, D., O’Dwyer, L. \& O'Connor, K. (2003). Examining teacher technology use: Implications for preservice and inservice teacher preparation. Journal of Teacher Education, 54(4), 297-310. http: / / dx.doi.org/10.1177/0022487103255985

Sasseville, B. (2004). Integrating information and communication technology in classroom: A comparative discourse analysis. Canadian Journal of Learning and Technology, 30(2), 5-27. http: / / www.cjlt.ca/index.php/cjlt/article/view /130/124

Schrum, L. (1999). Technology professional development for teachers. Educational Technology Research and Development, 47(4), 83-90. http: / /dx.doi.org/10.1007/BF02299599

Schwarz, C. (2005). Elementary/middle school science methods course at Michigan State University. Contemporary Issues in Technology and Teacher Education, 5(1).

http: / / www.citejournal.org/articles / mc3.html

Shulman, L. (1986). Those who understand: Knowledge growth in teaching. Educational Researcher, 15(2), 4-14. http:/ / dx.doi.org/10.3102/0013189X015002004

Song, J., Liang, G., Liu, G., Walls, R., Li, G., Wang, Z. \& Yin, H. (2005). Are teachers in China ready to teach in the 21st century? Journal of Technology and Teacher Education, 13(2), 197-209. http:/ / www.editlib.org/p/26104

Tao, P-K. \& Gunstone, R. F. (1999). Conceptual change in science through collaborative learning at the computer. International Journal of Science Education, 21, 39-57. http: / / dx.doi.org/10.1080/095006999290822

Teo, T. (2008). Pre-service teachers' attitudes towards computer use: A Singapore survey. Australasian Journal of Educational Technology, 24(4), 413-424. http: / / www.ascilite.org.au/ajet/ajet24/teo.html

Toomey, R. \& Ketterer, K. (1995). Using multimedia as a cognitive tool. Journal of Computing in Education, 27, 472-482.

Yildirim, S. (2000). Effects of an educational computing course on preservice and inservice teachers: A discussion and analysis of attitudes and use. Journal of Research on Computing in Education, 32(4), 479-495. 
Yin, R. K. (2009). Case study research: Design and methods (4th ed.). Thousand Oaks, CA: SAGE Publications, Inc.

Zhang, Z. \& Martinovic, D. (2008). ICT in teacher education: Examining needs, expectations and attitudes. Canadian Journal of Learning and Technology, 34(2), 149-166. http: / / www.cjlt.ca / index.php/cjlt/article/ viewArticle/498/229

Zhou, J. (2005). A study of academic staff development in Chinese higher education institutions. Department of Education \& Professional Studies, p.343. London: King's College London.

Zhou, G., Brouwer, W., Nocente, N. \& Martin, B. (2005). Enhancing conceptual learning through computer-based applets: The effectiveness and implications. Journal of Interactive Learning Research, 16(1), 31-49. http: / / www.editlib.org/p/4918

Zhou, G., Varnhagen, S., Sears, M., Kasprzak, S. \& Shervey, G. (2007). Online professional development for inservice teachers in information and communication technology: Potentials and challenges. Canadian Journal of Learning and Technology, 33(2), 123-143. http: / / www.cjlt.ca/index.php/cjlt/article/view / 2 /6

Zhou, G. \& Xu, J. (2007). Adoption of educational technology ten year after setting strategic goals: A Canadian university case. Australasian Journal of Educational Technology, 23(4), 508528. http:/ / www.ascilite.org.au/ajet/ajet23/ zhou.html

Zhou, G. \& Xu, J. (2011). Technology capacity building for preservice teachers through methods courses. International Journal of Online Pedagogy and Course Design, 1(3), 49-61. http: / / dx.doi.org/10.4018/ijopcd.2011070104

Zhu, Z. \& Gu, X. (2007). An e-education approach to teacher professional development in China. Digital Learning, June. http: / / www.digitallearning.in/articles/articledetails.asp?articleid=1244\&typ=COUNTRY\%20FOCUS; http: / / www.digitallearning.in / articles / index.asp?Month=6\&Year=2007\&page=2

Authors: Dr George Zhou, Associate Professor Faculty of Education, University of Windsor 401 Sunset Avenue, Windsor Ontario, Canada N9B 3P4 Email: gzhou@uwindsor.ca Web: http:/ / www.uwindsor.ca /

Dr Zuochen Zhang, Associate Professor Faculty of Education, University of Windsor 401 Sunset Avenue, Windsor Ontario, Canada N9B 3P4 Email: zuochen@uwindsor.ca Web: http: / / www.uwindsor.ca/

Yueke Li, Associate Professor School of Media and Communication Technology Liaocheng University 34, Wenhua Road, Liaocheng, Shandong 252059 China Email: liyueke@lcu.edu.cn Web: http:/ / www.lcu.edu.cn/en/

Please cite as: Zhou, G., Zhang, Z. \& Li, Y. (2011). Are secondary preservice teachers well prepared to teach with technology? A case study from China. Australasian Journal of Educational Technology, 27(6), 943-960. http: / / www.ascilite.org.au/ajet/ajet27/zhou.html 